\title{
Hubungan Pemberian Makanan Pendamping Asi Dini dengan Status Gizi Bayi 0-11 Bulan di Puskesmas Bangko Rokan Hilir
}

\section{The Association Between Complementary Feeding of Breast Milk And Health of Infants 0-11 MOnths In Puskesmas Bangko Rokan Hilir}

\section{Winda Septiani}

\section{Program Studi Magister Ilmu Kesehatan Masyarakat STIKes Hang Tuah Pekanbaru}

\begin{abstract}
ABSTRAK
Masalah dalam penelitian ini adalah masih rendahnya persentase ASI eksklusif dan tingginya persentase pemberian MP-ASI dini pada bayi 0-11 bulan di Kelurahan Bagan Barat Wilayah Kerja Puskesmas Bangko Rokan Hilir. Penelitian ini bertujuan untuk mengetahui hubungan pemberian MP-ASI dini dengan status gizi bayi 0-11 bulan di Kelurahan Bagan Barat Wilayah Kerja Puskesmas Bangko Rokan Hilir. Jenis penelitian adalah kuantitatif dengan jenis disain penelitian cross sectional. Dilaksanakan di Kelurahan Bagan Barat Wilayah Kerja Puskesmas Bangko Rokan Hilir dari tanggal 20 Mei hingga 20 Juni 2011, dengan jumlah sampel 67 responden yang diambil dengan menggunakan teknik Proporsional Random Sampling. Pengumpulan data dilakukan dengan metode wawancara menggunakan kuesioner dan analisis yang digunakan adalah univariat, bivariat duiji dengan uji chi-square dan multivariate diuji dengan uji regression logistic ganda. Hasil penelitian ini didapatkan bahwa prevalensi gizi kurang sebesar 31,1\%. Rata-rata umur pemberian MP-ASI dini $<6$ bulan sebesar 59,7\%. Dari hasil analisis multivariate didapatkan adanya hubungan yang bermakna antara pemberian MP-ASI dini dengan status gizi bayi 0 -11 bulan. Bayi yang diberi MP-ASI $<6$ bulan mempunyai peluang bayinya berstatus gizi tidak normal 16,694 kali dibandingkan dengan bayi yang diberi MP-ASI $\geq 6$ bulan setelah dikontrol oleh pendidikan, pengetahuan dan pekerjaan.
\end{abstract}

Kata Kunci: MP-ASI dini, Status Gizi Bayi

\section{ABSTRACT}

The issue in this research is still low percentage breast-fed exclusive and high the percentage of granting dishes breast milk early in infants 0-11 month in districts chart of the western region of work puskesmas Bangko Rokan Hilir. This research aimed at granting dishes - breast milk early to see relations with nutrition status of baby 0-11 months in districts chart of the western region of work puskesmas Bangko Rokan Hilir. This research is research quantitative with the type of design research cross sectional. Held in districts chart of the western region of work puskesmas bangko rokan hilir from the date 20 may to 20 june 2011, with the number of samples taken with 67 a respondent who uses the technique proportionate random sampling. An interview conducted with a method of collecting data and analysis using a questionnaire used is univariat, bivariat duiji by test chi-square and multivariate tested with the regression safinat logistic uppercut. This research result got that the prevalence of malnutrition by $31,1 \%$.The average age of granting dishes - breast milk early \& $<$ six months of 59,7\%.Analysis of the results obtained the multivariate meaningfui relations between the provision of dishes - breast milk early with nutrition status of baby 0-11 months. An infant who is given dishes - breast milk < six months have a chance the baby' s status is not normal nutrition 16,694 times compared with an infant who is given dishes - breast milk > six months after controlled by education, knowledge and work.

Keywords: dishes - breast milk early, nutrition status of baby

\section{PENDAHULUAN}

Pada tahun 2010 Angka Kematian Bayi (AKB) di Indonesia termasuk salah satu yang paling tinggi di dunia yaitu sebesar 28,94 kematian per 1.000 kelahiran hidup. Hal itu tercermin dari perbandingan dengan jumlah AKB di negara tetangga seperti Malaysia yang telah mencapai 10 per 1.000 kelahiran hidup dan Singapura dengan 5 per 1.000 kelahiran hidup. Tahun 2010 jumlah kematian bayi di Propinsi Riau mencapai 13,87 dari 1000 kelahiran hidup yang tersebar di 12 Kabupaten/Kota. Sedangkan untuk Kabupaten Rokan Hilir jumlah kematian bayi mencapai 63,54 dari 1000 kelahiran hidup. Riset Kesehatan Dasar Depkes 2007, menunjukkan bahwa kematian bayi baru lahir (neonatus) merupakan penyumbang kematian terbesar pada tingginya angka kematian balita (AKB). Setiap tahun sekitar 20 bayi per 1.000 kelahiran hidup terenggut nyawanya dalam rentang waktu $0-12$ hari pasca kelahirannya (Depkes, 2007).

Berdasarkan laporan status gizi di Provinsi Riau dari hasil penimbangan tahun 2009 sebanyak 436,189 Pada tahun 2009 Kabupaten Rokan Hilir memiliki masalah gizi dengan prevalensi sebesar $8,5 \%$ (4.583 orang) dari jumlah anak balita 54.512 dengan 
jumlah kasus anak balita gizi buruk sebanyak 581 orang $(1,1 \%)$, jumlah kasus gizi kurang sebanyak 3.483 orang $(6,4 \%)$ dan jumlah kasus gizi lebih 519 orang $(1,0 \%)$. Dari data ini dapat disimpulkan bahwa Kabupaten Rokan Hilir berada pada kondisi rawan gizi dimana prevalensi gizi buruknya $>1 \%$, gizi kurangnya $>5 \%$. Sedangkan pada tahun 2010 dengan jumlah kasus anak balita gizi buruknya sebanyak 56 orang $(1,8)$, gizi kurang 377 orang $(12,0 \%)$ dan jumlah gizi lebih 75 orang $(2,4 \%)$. Sehingga dapat disimpulkan bahwa terjadi penurunan pada tahun 2010 .

Pada Tahun 2009 Kelurahan Bagan Barat mempunyai masalah gizi dengan prevalensi $36,3 \%$ dari jumlah anak balita 1.153 orang, dengan jumlah kasus anak balita gizi buruk 2 orang $(1,2 \%)$ dan jumlah kasus gizi kurang 93 orang $(35,1 \%)$. Sedangkan pada tahun 2010 prevalensi masalah gizinya sebesar $7,5 \%$ dari jumlah anak balita 1.014 orang, dengan jumlah kasus gizi anak balita gizi buruk sebanyak 2 orang $(1,1 \%)$ dan jumlah kasus gizi kurangnya sebanyak 21 orang $(6,4 \%)$.

Dari data tersebut dapat disimpulkan bahwa Kelurahan Bagan Barat berada pada kondisi rawan gizi dimana prevalensinya gizi buruknya $>1 \%$ dan gizi kurangnya $>5 \%$, jika dibandingkan dengan prevalensi gizi buruk dan gizi kurang dikatakan menjadi suatu masalah kesehatan masyarakat apabila prevalensinya $>1 \%$ dan $5 \%$, maka jumlah tersebut merupakan jumlah yang melebihi target.

Pada usia 0-6 bulan, bayi hanya diberi ASI saja (pemberian ASI Eksklusif), karena produksi ASI pada periode tersebut sudah mencukupi kebutuhan bayi untuk tumbuh kembang yang sehat. Pemberian makanan selain ASI pada umur 0-6 bulan dapat membahayakan bayi, karena bayi belum mampu memproduksi enzim untuk mencerna makanan selain ASI (Depkes RI, 2003).

Makanan bayi yang paling utama adalah Air Susu Ibu (ASI) karena ASI mengandung hampir semua zat gizi dengan komposisi sesuai kebutuhan bayi tetapi kecukupan komposisinya hanya sampai usia empat bulan. Cadangan vitamin dan mineral dalam tubuh bayi yang didapat dari ibu semasa dalam kandungan dan selama usia tiga bulan sejak lahir sudah mulai menurun, sedangkan dari ASI kandungan vitamin A dan C serta zat besi sudah tidak begitu tinggi karena itu sejak usia empat bulan sudah perlu diberikan makanan tambahan yang mengandung vitamin dan mineral selain tetap memberikan ASI. Pada usia 6 bulan pencernaan bayi mulai kuat sehingga pemberian MPASI bisa diberikan karena jika terlalu dini akan menurunkan konsumsi ASI dan mengalami gangguan pencernaan tetapi apabila terlambat akan menyebabkan kurang gizi bila terjadi dalam waktu yang panjang (Baso, 2007).

Berdasarkan profil Dinas Kesehatan Provinsi Riau tahun 2010 bayi yang diberi MP-ASI dini sebanyak 73,50\%, hal ini dapat dilihat dari cakupan ASI Eksklusif yang ada yaitu sebesar 26,50\%. Berdasarkan profil Dinas Kesehatan Kota Bagansiapiapi Kabupaten Rokan Hilir tahun 2010 cakupan ASI Eksklusif yaitu sebesar 46,35\% jadi dapat ditarik kesimpulan bahwa yang mendapat MP-ASI dini yaitu sebesar $53,65 \%$ dengan jumlah sasaran 12.117 bayi yang terdiri dari 15 Puskesmas. Cakupan ASI Eksklusif yang paling rendah terdapat pada Puskesmas Bangko yang meliputi 17 kelurahan yaitu sebesar $63,80 \%$ dengan jumlah sasaran bayi 977 bayi 0-6 bulan dan kelurahan yang paling rendah cakupan ASI Eksklusifnya adalah Kelurahan Bagan Barat yaitu $31,7 \%$ jadi bayi yang diberi MP-ASI dini sebesar $68,3 \%$. Dari data tersebut dapat ditarik kesimpulan bahwa di Puskesmas Bangko masih banyak bayi yang diberi MP-ASI dini yaitu sebesar $36,20 \%$.

Penelitian Sri Wulan Sari di Puskesmas Garuda Kota Pekanbaru juga menunjukan bahwa MPASI dini sudah diberikan kepada bayi sebagian besar oleh ibu yang berpengetahuan rendah (79\%), ibu yang bekerja $(93,2 \%)$ dan ibu dengan berpendidikan rendah (74,7\%). Pemberian MP-ASI dini juga berpengaruh terhadap status gizi bayi berdasarkan $\mathrm{BB} / \mathrm{U}$ dan $\mathrm{BB} / \mathrm{PB}$. Sebagian besar status gizi bayi yang diberi MP-ASI dini termasuk kategori kurang baik, yaitu $(7,5 \%)$ berdasarkan indeks $\mathrm{BB} / \mathrm{U}$ dan $(28 \%)$ berdasarkan indeks BB/PB.

Tujuan dari penelitian ini adalah untuk mengetahui hubungan pemberian MP-ASI dini dengan status gizi bayi $0-11$ bulan berdasarkan $\mathrm{BB} / \mathrm{PB}$ di wilayah kerja Puskesmas Bangko Kelurahan Bagan Barat Rokan Hilir.

\section{METODE}

Penelitian ini dilakukan dengan menggunakan metode penelitian kuantitatif analitik dengan desain studi penampang analitik (analytic cross-sectional Study). Subjek penelitian adalah bayi 0-11 bulan di Kelurahan Bagan Barat wilayah Kerja Puskesmas Bangko dengan populasi seluruh bayi yang berjumlah 360 bayi. Sampel yang diambil adalah bayi yang terpilih sebagai subjek total penelitian yang berada di Kelurahan Bagan Barat di wilayah kerja Puskesmas Bangko. Sampel yang diambil adalah bayi yang terpilih sebagai subjek total penelitian yang berada di Kelurahan Bagan Barat di wilayah kerja Puskesmas Bangko yang dihitung dengan menggunakan rumus besar sampel berdasarkan formula Lemeshow (1997), sehingga didapatkan sampel sebanyak 67 sampel. Responden Penelitian ini adalah ibu bayi atau anggota keluarga yang dapat memberikan keterangan yang akurat tentang subjek dan hal-hal yang berkaitan dengan aktivitas keluarga dalam gizi dalam. Pengetahuan Ibu diukur dengan cara melakukan wawancara dengan kategori baik apabila responden dapat menjawab $12-20$ pertanyaan $(\geq 60 \%)$ dan 
kategori kurang apabila responden dapat menjawab < 12 pertanyaan $(<60 \%)$. Penelitian ini menggunakan sistem Propotional Random Sampling dengan memperhitungkan proporsi atau jumlah populasi bayi 0-11 bulan pada wilayah Kelurahan Bagan Barat yang diukur berdasarkan Berat Badan dibagi dengan Panjang Badan (BB/PB). Data dikumpulkan pada bulan Juni 2011 bertempat di 7 Posyandu yang ada di Kelurahan Bagan Barat wilayah Kerja Puskesmas Bangko dengan cara mengunjungi Posyandu dan membagikan kuesioner (angket) kepada responden, dan disertai dengan melakukan wawancara tertutup. Analisis data menggunakan teknik analisis Regresi Logistik Ganda dengan analisis multivariat.

\section{HASIL}

\section{Analisis Univariat}

Hasil analisis univariat menunjukkan bahwa sebagian besar bayi (59,7\%) sudah diberi MP-ASI $<6$ bulan. Berdasarkan karakteristik subjek penelitian ditemui bahwa sebagian besar sampel berada pada kelompok umur $\geq 6$ bulan sebanyak $(64,2 \%)$. Sebagian besar sampel berjenis kelamin laki-laki $(52,2 \%)$ dan sebagian besar sampel berstatus gizi tidak normal $(31,1 \%)$. Berdasarkan pada karakteristik responden, sebagian besar responden berpendidikan rendah $(65,7 \%)$ dengan status pekerjaan responden sebagian besar tidak bekerja $(70,1 \%)$. Adapun dilihat dari pola pemberian MP-ASI sebagian besar sampel sudah diberi MP-ASI $<6$ bulan $(59,7 \%)$ dimana alasan pemberian disebabkan karena ASI tidak cukup $(46,3 \%)$ (tabe1 1).

\section{Analisis Bivariat}

Analisis bivariat dengan uji Chi Square menunjukkan bahwa variabel yang berhubungan dengan Status Gizi Bayi 0-11 Bulan berdasarkan $\mathrm{BB} / \mathrm{PB}$ adalah variabel pemberian MP-ASI Dini (POR 6,545 95\% CI:1,693-25,305), pekerjaan (POR 6,333 95\% CI:2,000-20,052), pendidikan (POR 7,980 95\% CI:1,663-38,291) (tabel 2).

\section{Analisis Multivariat}

Berdasarkan uji seleksi bivariat, terdapat 4 variabel yang dijadikan sebagai kandidat multivariat $(\mathrm{p}<0,25)$, yaitu variabel pemberian MP-ASI Dini, Pengetahuan, Pekerjaan dan Pendidikan.

Hasil akhir pemodelan multivariat, didapatkan 4 variabel yang berhubungan signifikan dengan pemanfaatan status gizi bayi yaitu variabel MP-ASI, Pendidikan, Pengetahuan dan pekerjaan. Variabel pendidikan, pengetahuan dan pekerjaan merupakan variabel kounfounding. Variabel pemberian MP-ASI dini sebagai variabel utama yang mempengaruhi status gizi bayi setelah dikontrol oleh variabel pendidikan, pengetahuan dan pekerjaan. Bayi yang diberi MP-ASI dini $<6$ bulan mempunyai peluang bayinya berstatus gizi tidak normal 16,694 kali dibandingkan dengan pemberian MP-ASI $>6$ bulan setelah dikontrol oleh variabel pendidikan, pengetahuan dan pekerjaan (tabel $3)$.

Tabel 1

Hasil Analisis Univariat $(n=67)$

\begin{tabular}{|c|c|c|}
\hline Variabel & Jumlah & Persentase \\
\hline \multicolumn{3}{|l|}{ Karakteristik Subjek } \\
\hline \multicolumn{3}{|l|}{ Penelitian } \\
\hline \multicolumn{3}{|l|}{ Umur Bayi } \\
\hline 1. $\geq 6$ bulan & 43 & 64,2 \\
\hline 2. $<6$ bulan & 24 & 35,8 \\
\hline \multicolumn{3}{|l|}{ Jenis Kelamin } \\
\hline 1. Laki-laki & 35 & 52,2 \\
\hline 2. Perempuan & 32 & 47,8 \\
\hline \multicolumn{3}{|l|}{ Status Gizi Bayi berdasarkan } \\
\hline \multicolumn{3}{|l|}{$\mathrm{BB} / \mathrm{PB}$} \\
\hline 1. Normal & 46 & 68,7 \\
\hline \multicolumn{3}{|l|}{ 2. Tidak Normal: } \\
\hline Kurus & 9 & 13,4 \\
\hline Gemuk & 12 & 17,9 \\
\hline \multicolumn{3}{|l|}{ Karakteristik Responden } \\
\hline \multicolumn{3}{|l|}{ Pendidikan } \\
\hline 1. Tinggi (SMA-PT) & 23 & 34,3 \\
\hline 2. Rendah (SD/SMP) & 44 & 65,7 \\
\hline \multicolumn{3}{|l|}{ Status Pekerjaan } \\
\hline 1. Tidak Bekerja & 47 & 70,1 \\
\hline 2. Bekerja & 20 & 29,9 \\
\hline \multicolumn{3}{|l|}{ Pengetahuan } \\
\hline 1. Baik & 32 & 47,8 \\
\hline 2. Kurang & 35 & 52,5 \\
\hline \multicolumn{3}{|l|}{ Pola Pemberian MP-ASI } \\
\hline $\begin{array}{l}\text { 1. Diberi MP-ASI } \geq 6 \\
\text { bulan }\end{array}$ & 27 & 40,3 \\
\hline $\begin{array}{l}\text { 2. Diberi MP-ASI }<6 \\
\text { bulan }\end{array}$ & 40 & 59,7 \\
\hline \multirow{2}{*}{\multicolumn{3}{|c|}{$\begin{array}{c}\text { Alasan Pemberian MP-ASI } \\
\text { Dini }\end{array}$}} \\
\hline & & \\
\hline 1. ASI tidak cukup & 31 & 46,3 \\
\hline 2. ASI tidak keluar & 9 & 13,4 \\
\hline 3. Memenuhi gizi bayi & 18 & 26,9 \\
\hline 4. Kebiasaan Keluarga & 9 & 13,4 \\
\hline
\end{tabular}

Tabel 3.

Permodelan Lengkap Multivariat (Akhir)

\begin{tabular}{lllll}
\hline & & & \multicolumn{2}{c}{$\mathbf{9 5 . 0 \%}$ C.I. for } \\
\cline { 4 - 5 } Variabel & Pv & $\operatorname{Exp}(B)$ & Lower & Upper \\
\hline MP-ASI dini & 0,005 & $\mathbf{1 6 , 6 9 4}$ & 2,364 & 117,884 \\
Pendidikan & 0,026 & 9,214 & 1,298 & 65,749 \\
Pengetahuan & 0,017 & 10,033 & 1,508 & 66,749 \\
Pekerjaan & 0,003 & 16,619 & 2,612 & 105,749 \\
\hline
\end{tabular}


Tabel 2

Hasil Analisis Bivariat

\begin{tabular}{|c|c|c|c|c|c|}
\hline \multirow[t]{3}{*}{ Variabel } & \multicolumn{2}{|c|}{ Status Gizi } & \multirow[t]{2}{*}{ Total } & \multirow{3}{*}{$\begin{array}{c}\mathrm{P} \\
\text { value }\end{array}$} & \multirow{3}{*}{$\begin{array}{c}\text { OR } \\
(95 \% \mathrm{CI})\end{array}$} \\
\hline & Normal & Tidak Normal & & & \\
\hline & $\mathrm{n}(\%)$ & $\mathrm{n}(\%)$ & $\mathrm{N}(\%)$ & & \\
\hline \multicolumn{6}{|l|}{ Pemberian MP-ASI Dini } \\
\hline Tidak diberi MP-ASI (diberi $\geq 6$ bulan & $24(88,9)$ & $3(11,1)$ & $27(100,0)$ & \multirow{3}{*}{0,008} & \multirow{3}{*}{$\begin{array}{c}6,545(1,693- \\
25,305)\end{array}$} \\
\hline Diberi MP-ASI (diberi < 6 bulan) & $22(55,0)$ & $18(45,0)$ & $40(100,0)$ & & \\
\hline Jumlah & $46(68,7)$ & $21(31,1)$ & $67(100,0)$ & & \\
\hline \multicolumn{6}{|l|}{ Pengetahuan } \\
\hline $\begin{array}{l}\text { Baik } \\
\text { Kurang }\end{array}$ & $19(52,8)$ & $17(47,2)$ & $36(100,0)$ & \multirow{2}{*}{0,006} & \multirow{2}{*}{$\begin{array}{c}6,039(1,753- \\
20,813)\end{array}$} \\
\hline $\begin{array}{l}\text { Kurang } \\
\text { Jumlah }\end{array}$ & $46(68,7)$ & $21(31,3)$ & $67(100,0)$ & & \\
\hline \multicolumn{6}{|l|}{ Pekerjaan } \\
\hline Tidak Bekerja & $8(40,8)$ & $12(60,2)$ & $20(100,0)$ & \multirow{2}{*}{0,003} & \multirow{2}{*}{$\begin{array}{l}6,333(2,000- \\
\quad 20,052)\end{array}$} \\
\hline $\begin{array}{l}\text { Bekerja } \\
\text { Jumlah }\end{array}$ & $46(68,7)$ & $21(31,3)$ & $67(100,0)$ & & \\
\hline \multicolumn{6}{|l|}{ Pendidikan } \\
\hline Tinggi & $21(91,3)$ & $2(8,7)$ & $23(100,0)$ & \multirow{3}{*}{0,009} & \multirow{3}{*}{$\begin{array}{c}7,980(1,663 \\
38,291)\end{array}$} \\
\hline Rendah & $25(56,8)$ & $19(43,2)$ & $44(100,0)$ & & \\
\hline Jumlah & $46(68,7)$ & $21(31,3)$ & $67(100,0)$ & & \\
\hline
\end{tabular}

\section{PEMBAHASAN}

\section{Pemberian MP-ASI Dini}

Dari hasil penelitian didapatkan bahwa bayi yang berumur $<6$ bulan sudah diberikan MP-ASI dini sebesar 59,7\%. Kemungkinan hal ini disebabkan karena adanya tradisi masyarakat secara turun temurun yang masih kuat dalam hal bahwa bayi yang gemuk itu sehat sehingga MP-ASI cepat diberikan meski bayi masih berumur $<6$ bulan. Bayi yang memiliki status gizi tidak normal (kurus) juga banyak terdapat pada golongan masyarakat miskin yang bila memberikan susu formula seringkali dilakukan pengenceran yang tidak sesuai dengan takaran sehingga jumlah asupan zat gizi yang dikonsumsi bayi tidak sesuai dengan kebutuhannya.

Dari hasil penelitian yang dilakukan dapat dilihat bahwa di Kelurahan Bagan Barat memiliki persentase bayi yang diberikan MP-ASI $<6$ bulan $(45,0 \%)$ berstatus gizi tidak normal lebih banyak dibandingkan dengan bayi yang diberikan MP-ASI $\geq 6$ bulan $(11,1 \%)$. Ada hubungan antara pemberian MPASI dini dengan status gizi bayi. Analisis keeratan hubungan kedua variabel adalah bayi yang diberi MPASI $<6$ bulan mempunyai peluang status gizi tidak normal 6,545 kali dibandingkan dengan bayi yang diberikan MP-ASI $\geq 6$ bulan.

Dari hasil penelitian Wulan Sari (2009), juga menyimpulkan bahwa ada hubungan antara pemberian MP-ASI dengan status gizi bayi $0-11$ bulan berdasarkan $\mathrm{BB} / \mathrm{U}$ dan $\mathrm{BB} / \mathrm{PB}$, hasil analaisi diperoleh $\mathrm{p}=0,073$ dan $\mathrm{p}=0,000$.
Pemberian MP-ASI dini sebagai variabel utama yang mempengaruhi status gizi bayi setelah dikontrol oleh variabel pendidikan, pengetahuan dan pekerjaan. Bayi yang diberi MP-ASI dini $<6$ bulan mempunyai peluang bayinya berstatus gizi tidak normal 16,694 kali dibandingkan dengan pemberian MP-ASI $>6$ bulan.

Bayi yang tidak diberi MP-ASI dini status gizinya lebih baik bila dibandingkan dengan bayi yang sudah diberi MP-ASI dini, dari data yang ada diketahui bahwa ibu sudah memberikan MP-ASI kepada bayinya sejak usia $<6$ bulan $(59,7 \%)$ dengan alasan diantaranya ASI tidak cukup (46,3\%), ASI tidak keluar $(13,4 \%)$, Memenuhi zat gizi bayi $(26,9 \%)$ dan kebiasaan keluarga $(13,4 \%)$.

\section{Pengetahuan}

Dari hasil penelitian didapatkan bahwa ibu yang mempunyai tingkat pengetahuan yang kurang sebesar $52,2 \%$. Pengetahuan ibu yang kurang dalam hal memenuhi status gizi bayi ini kemungkinan disebabkan oleh ibu-ibu mempunyai jenjang pendidikan yang rendah (tidak sekolah/tamat SD) serta disebabkan oleh ibu-ibu kebanyakan hanya berdiam diri dirumah (tidak bekerja) sehingga kurang mendapatkan informasi - informasi penting mengenai kesehatan.

Pengetahuan Ibu mengenai MP-ASI juga sangat rendah. Hal ini disebabkan oleh ibu-ibu jarang membawa bayinya ke Posyandu sehingga ibu-ibu tidak mendapatkan informasi-informasi mengenai kesehatan yang ada di Posyandu tersebut. 
Berdasarkan hasil penelitian yang telah dilakukan terhadap 67 responden diperoleh hasil bahwa mayoritas ibu berpengetahuan baik cenderung memiliki bayi dengan status gizi normal yaitu sebanyak 27 orang $(87,1 \%)$. Hal ini ditunjukkan dari hasil uji statistic dengan metode chi square diperoleh nilai $p=0,006$ artinya terdapat hubungan antara pengetahuan ibu dengan status gizi bayi.

Hasil penelitian ini sejalan dengan hasil penelitian Trisnawati (2009), juga menyimpulkan bahwa ada hubungan antara tingkat pengetahuan dengan status anak. Dari hasil analaisi diperoleh $p=0,003$. Hal ini artinya ada hubungan yang bermakna antara pengetahuan dengan status gizi anak balita.

\section{Pekerjaan}

Dari hasil penelitian didapatkan bahwa ibu yang berstatus tidak bekerja sebesar $70,1 \%$. Ibu yang tidak bekerja berkemungkinan mempunyai waktu yang banyak untuk dapat mengurus atau merawat bayinya dengan baik dalam hal pemenuhan zat gizi.

Berdasarkan hasil penelitian yang yang telah dilakukan terhadap 67 responden diperoleh hasil bahwa mayoritas ibu tidak bekerja cenderung memiliki balita dengan status gizi normal sebanyak 38 orang (80,9\%). Hal ini ditunjukkan dari hasil uji statistik dengan metode chi square diperoleh nilai $p=0,003$ $(p<0,05)$ artinya terdapat hubungan antara status pekerjaan ibu dengan status gizi bayi.

Status pekerjaan Ibu juga dapat mempengaruhi dalam pemberian MP-ASI dini. Ibu yang tidak bekerja lebih berisiko dalam pemberian MP-ASI dini. Hal ini disebabkan karena ibu-ibu hanya berdiam diri dirumah sehingga $\mathrm{ibu}-\mathrm{ibu}$ tidak mendapatkan informasi mengenai kesehatan disusul masih kuatnya pengaruh sosial budaya yang masih kental dalam hal bayi yang cepat diberi makan akan gemuk, dan gemuk itu sehat. Hal ini dikuatkan juga dengan hasil penelitian yang dilakukan oleh Balkis Alkarim (2010) terhadap 90 responden diperoleh hasil bahwa mayoritas ibu yang tidak bekerja cenderung memiliki balita dengan status gizi normal yaitu sequarbanyak 46 orang $(68,7 \%)$. Hal ini ditunjukkan dari hasil uji statistik dengan metode chi square diperoleh nilai $p=0,024(p<0,05)$ artinya terdapat hubungan antara status pekerjaan ibu dengan status gizi balita

\section{Pendidikan}

Dari hasil penelitian dapat dilihat bahwa responden dengan tingkat pendidikan yang rendah (SD-SMP) sebesar 65,7\%. Hal ini disebabkan oleh adanya ketidakmampuan keluarga (sosial ekonomi) dalam meneruskan pendidikan serta masih adanya anggapan bahwa pendidikan SD sudah cukup karena pada saat itu seseorang sudah bisa membaca dan menulis. Pendidikan yang rendah akan mempunyai tingkat pengetahuan yang kurang bila dibandingkan dengan tingkat pendidikan yang tinggi.

Tingkat pendidikan ibu juga dapat mempengaruhi dalam pemberian MP-ASI dini. Ibu dengan pendidikan rendah akan cenderung memberi bayinya MP-ASI dini. Hal ini disebabkan karena ibuibu tidak tahu waktu tepat dalam pemberian MP-ASI.

Berdasarkan hasil penelitian yang telah dilakukan terhadap 67 responden diperoleh hasil bahwa mayoritas ibu berpendidikan tinggi cenderung memiliki bayi dengan status gizi normal 21 orang $(91,3 \%)$. Hal ini ditunjukkan dari hasil uji statistik dengan metode chi square diperoleh nilai $p=0,009$ $(p<0,05)$ artinya terdapat hubungan antara pendidikan ibu dengan status gizi bayi.

Tidak jauh beda dengan hasil penelitian Himawan (2006) di Kelurahan Sakaran Kecamatan Gunung Pati Semarang, ada hubungan antara tingkat pendidikan ibu dengan status gizi balita, karena tingkat pendidikan akan mempermudah seseorang menerima informasi termasuk informasi gizi dan kesehatan sehingga dapat meningkatkan pengetahuan yang akan menimbulkan sifat yang positif dibidang kesehatan. Keadaan ini akan mencegah masalah gizi yang tidak diinginkan.

\section{KESIMPULAN}

Pada Analisis multivariat menunjukkan bahwa variabel yang paling dominan berpengaruh terhadap status gizi bayi adalah pemberian MP-ASI Dini. Bayi yang diberi MP-ASI dini $<6$ bulan mempunyai peluang bayinya berstatus gizi tidak normal 16,694 kali dibandingkan dengan pemberian MP-ASI > 6 bulan setelah dikontrol oleh variabel pendidikan, pengetahuan dan pekerjaan.

\section{SARAN}

Hasil penelitian menunjukkan bahwa pemberian MP-ASI Dini $<6$ bulan dapat mempengaruhi status gizi bayi. Diharapkan bagi Ibuibu agar tetap memberikan ASI Eksklusif kepada bayinya. Bagi Puskesmas Bangko, perlu diadakannya penyuluhan di lingkungan masyarakat untuk ibu-ibu yang tidak mendatangi posyandu, serta membuat informasi kesehatan melalui brosur-brosur kesehatan dan lain sebagainya yang bertujuan untuk meningkatkan informasi dan pemahaman ibu tentang MP-ASI.

\section{DAFTAR PUSTAKA}

Balkis Alkarim, P. (2010). Hubungan Karakteristik Ibu dengan Status Gizi Balita. Program Sarjana FKM STIKes Hang Tuah Pekanbaru.

Baso, M. (2007). Studi Longitudinal Pertumbuhan Bayi yang diberi MP-ASI (Blended food) dan 
MP-ASI Non-pabrik (Local Food). (http://www.blogsome.com, diakses 2 februari 2011).

Dinas Kesehatan Provinsi Riau. (2010). Dalam Data. Cakupan ASI Eksklusif Provinsi Riau.

Dinas Kesehatan Provinsi Riau. (2010). Dalam Data. Jumlah Kematian Bayi Provinsi Riau.

Dinas Kesehatan Kabupaten Rokan Hilir. (2010). Dalam Data. Profil Kesehatan Kabupaten Rokan Hilir Tahun 2010. Rokan Hilir: Dinas Kesehatan.

Depkes, (2007). Pedoman Umum Gizi Seimbang.
Himawan, Arif Wahyu (2006). Hubungan Antara Karakterisrik Ibu dengan Status Gizi Balita di Kelurahan Sakaran Kecamatan Gunung Pati Semarang. Universitas Negeri Semarang.

Trisnawati, E. (2009). Faktor-faktor yang Berhubungan dengan Status Gizi Anak Usia 612 bulan. Program Sarjana FKM STIKes Hang Tuah Pekanbaru.

Wulan Sari, S. (2009). Hubungan Pengetahuan, Status Pekerjaan, Pendidikan Ibu dengan Pemberian MP-ASI Dini Terhadap Status Gizi Bayi 0-11 bulan Berdasarkan $B B / U$ dan $B B / P B$. Program Sarjana FKM STIKes Hang Tuah Pekanbaru. 